\title{
Understanding COVID-19 Pandemic through Science, Technology and Society (STS) Education: A Textual Analysis of Student Reflection Papers
}

\section{Jerome V. Cleofas}

Department of Sociology and Behavioral Sciences, College of Liberal Arts, De La Salle University, 2401 Taft Ave, Malate, Manila, 1004 Metro Manila, Philippines

\begin{abstract}
The COVID-19 pandemic calls for educators to deliver learning experiences that are relevant in order to empower students to adapt to these unprecedented times. Science, Technology and Society (STS) is an interdisciplinary social science course included in the undergraduate general education curriculum in the Philippines that can potentially be designed to help students make sense of the coronavirus crisis. This study aims to describe the insights on the COVID-19 pandemic among undergraduate students enrolled in STS classes through the textual analysis of their reflection papers. A total of 74 reflection papers were qualitatively textually analysed using thematic analysis. Four themes emerged from the data: (1) appreciation of the science and medical community; (2) sensitivity to the barriers of scientific progress during the COVID-19 pandemic; (3) gaining social consciousness about the impacts of the pandemic, and; (4) enrichment of critical thinking and social engagement. Educators are encouraged to incorporate STS approaches in their lessons to foster students' critical understanding of current socio-scientific issues.
\end{abstract}

Keywords: COVID-19, pandemic, reflection papers, STS, STS education, textual analysis

\begin{tabular}{ll}
\hline & INTRODUCTION \\
& Globally, the COVID-19 pandemic has \\
& impacted all sectors of life. As of this \\
& writing, this disease has caused at least 2.4 \\
ARTICLE INFO & million deaths worldwide (World Health \\
\hline $\begin{array}{l}\text { Article history: } \\
\text { Received: 23 March 2021 }\end{array}$ & Organisation, 2021) and has interrupted \\
$\begin{array}{l}\text { Published: 24 September 2021 } \\
\text { DOI: https://doi.org/10.47836/pjssh.29.3.27 }\end{array}$ & social and economic systems. While the \\
\hline $\begin{array}{l}\text { E-mail address: } \\
\text { jerome.cleofas@dlsu.edu.ph }\end{array}$ & world is beginning to see progress in the \\
& management and mitigation of the spread
\end{tabular}


of the virus, the end of the pandemic and the dire consequences that come with it are still out of reach. One of the sectors that this disease has impacted is education. Abruptly, schools have transitioned from traditional classrooms to online set-ups. It has been difficult for teachers, students, administrators and other stakeholders (Cleofas, 2021; Talidong \& Toquero, 2020).

However, despite the many challenges that it had brought to learning institutions, this unprecedented public health crisis also brings new opportunities to the way education can be delivered to the students. This situation calls for teachers to enhance their e-learning competencies and innovate their teaching strategies to make their courses relevant. Furthermore, educators are encouraged to design their syllabus to maximise digital classrooms' potentials and empower students to respond to the societal impacts of COVID-19 (Toquero, 2020).

One subject that can provide students with a critical understanding of the pandemic and its consequences is Science, Technology and Society (STS) (Hodson, 2020). In the Philippines, STS has recently been introduced by the Commission on Higher Education (CHED, 2013) in the general education curriculum (GEC) in college after the country's basic educational landscape transitioned to K-12 (CHED, 2013). With less than ten years since its implementation, college-wide STS education is still in its infancy, and professors of this course are continually discovering and improving ways of handling this subject. More research about STS education at the college level in the Philippines is needed.
STS is a branch of social sciences that is interdisciplinary. It aims to develop students' critical understanding of how science and technology as a social institution shapes and is shaped by sociocultural, political and economic contexts (CHED, 2013; Chowdhury, 2016). Because COVID-19 is both a scientific (i.e. nature of the virus, development of treatment and vaccines, disease progression) and social phenomenon (i.e. human behavioural changes, socioeconomic consequences of quarantine, stigma and discrimination), STS education can help undergraduate students make sense of the pandemic as it unfolds in their lives in real-time (Hodson, 2020). In the Philippines, the coronavirus crisis has thrived in a sociopolitical background characterised by increased militarization and police brutality, distrust among public officials, censorship and populism, and digital, gender and economic inequality (Beltran, 2020; Lasco, 2020). STS education can equip young Filipinos with social and scientific consciousness to inspire them to address the earlier issues and contribute to nation-building during these challenging times.

\section{The Relevance of STS Education}

Outside the Philippines, there have been review papers and empirical evidence demonstrating the positive outcomes of STS education among students; studies have suggested that STS can increase science literacy and critical thinking (Mulyanti et al., 2020; Yapıc1oğlu \& Kaptan, 2017), foster changes in scientific attitudes such 
as suspension of belief and challenging authority (Çalik \& Karatas, 2019), enhance science motivation (Cigdemoglu, 2020), promote the use of moral judgments on socio-scientific issues (Yapıcıoglu \& Kaptan, 2017), sociopolitical awareness and engagement (Chowdhury et al., 2020) and even develop soft skills such as communication, interpersonal skills, and professionalism (Roswita et al., 2021).

STS contributes to the humanisation and socialisation of science (Chowdhury, 2016), which is running at a fast pace during this unprecedented public health crisis. Scholars have argued the relevance of STS education in the context of the COVID-19 pandemic. Hodson (2020) opined that during and beyond the pandemic is an opportune time to enhance the youth's STS postures towards socio-scientific issues to compel students to action parallel to social movements against different kinds of oppression. Knopes (2019) asserted the significance of using the STS lens in health and medicine for students and practitioners to gain a more critical appreciation of how illness events - such as COVID-19 - and medical technologies can impact patients' social lives. Feminist STS scholars suggested the importance of understanding the role of every individual in addressing COVID-19 and its consequences and other coinciding issues such as racism, gender inequality and anti-science movements (Fitsch et al., 2020).

\section{Research Objective}

Cognizant of the potentials of STS education in order to illuminate the COVID-19 phenomenon and dearth of literature about STS education, especially among undergraduate students and in the Philippine context, this study aims to describe the insights on the COVID-19 pandemic among undergraduate students enrolled in STS classes through the textual analysis of their reflection papers.

\section{METHODS}

This study utilised a qualitative textual analysis research design. Smith (2017) defines this as a research approach that examines messages found in various mediums and analyses them in the social contexts that they are situated. Smith (2017) explains that this design looks at the text to understand and make sense of social reality rather than measure or determine. For this study, the unit of analysis is the text from reflection papers produced by the undergraduate students as a terminal summative output for their STS class.

\section{Sample}

The reflection papers that were purposively selected for inclusion in the study were those submitted by undergraduate students who possessed the following criteria: (1) should be 18 years old, and above; (2) should be enrolled in any one of the three STS classes of the researcher who was also the STS instructor, and; (3) should have voluntarily provided their consent to have their paper included in the study. Thus, a total of 74 reflection papers from eligible students $(n=74)$ were included in the study. The majority of the participants were 18-year-old 
(38\%; $\mu=18.97)$, female $(63 \%)$ and in their first year of college (62\%), and belonged to various degree programs in business and liberal arts.

\section{Study Procedure}

Description of the STS Class. The STS classes spanned for one term (14 weeks) from July to October 2021. Because of the community quarantine, all university campuses are closed in the Philippines. Therefore, all classes were delivered purely online. The STS course included modular lessons on the following: nature and philosophies of science, the sociocultural, political, economic and historical context of science and technology, interdisciplinarity, futures of science and technology, technological impact assessment, and indigenous sciences.

The researcher/instructor employed a flipped classroom strategy where lectures are pre-recorded as videos and are asynchronously consumed by the students. Collaborative writing and/or creative assignments were consequently provided to students to demonstrate their learning on the topics and served as formative assessment activities. During synchronous classes via the Google Meet ${ }^{\circledR}$ video conferencing platform, the researcher/instructor would engage the students in discussions and debates about current local and global events and related socio-scientific issues, and then present and appraise the module outputs of the students to provide deeper insights and immediate feedback to the class. For example, emerging news about the COVID-19 pandemic and its response was frequent discussion points during classes. The use of interactive and reflective strategies embedded in current socioscientific issues in teaching STS, which were used to design this particular STS course, have been promoted by various STS researchers (Bettencourt et al., 2011; Chowdhury et al., 2020; Hodson, 2020; Knopes, 2019; Yapıcığlu \& Kaptan, 2017).

\section{Reflection Paper as The Research} Instrument. The main data source of this study is the text from student reflection papers, which were part of the summative assessment activities for the STS class. Reflection papers fit research that looks at students' social awareness and selfreflexivity (Olukotun et al., 2018). The reflection papers were submitted during the 12th week of the term, where all the didactics of the course had already been delivered. The students were instructed to answer the question, "how did the Science, Technology and Society class help you understand and cope with the COVID-19 pandemic?" In the instructions, the students were encouraged to make the sharing more personal. Except for a word count limitation of 1,000 words, no writing structure was prescribed. It is to ensure the writing to be unrestricted. These outputs were submitted as online texts through the university's learning management system (LMS).

Data Collection. Upon submission, the students are presented with the online informed consent form, showing details 
on the adherence of the study to Philippine national ethical standards for research and the Data Privacy Act, and asking whether they would like to volunteer their write up to be a part of the research. Upon securing consent, the reflection papers were stored in the qualitative data analysis software. The summary of research methods is found in Figure 1.

\section{Data Analysis}

Thematic analysis was used to generate findings that represent patterns in the textual data from the reflection papers. First, the researcher read and reread the text in order to gain familiarisation with the data. After which, codes were generated in order to reduce the data. Codes were further reduced to categories until themes were identified, reviewed and defined (Terry et al., 2017). This process is demonstrated through a sample excerpt in Table 1. Data analysis was managed using NVivo ${ }^{\circledR}$ qualitative data analysis software.

\section{RESULTS}

From the textual analysis of the 74 reflection papers, four major themes emerged: (1) appreciation of the science and medical community; (2) sensitivity to the barriers of scientific progress during the COVID-19 pandemic; (3) gaining social consciousness about the impacts of the pandemic, and; (4) enrichment of critical thinking and social engagement.

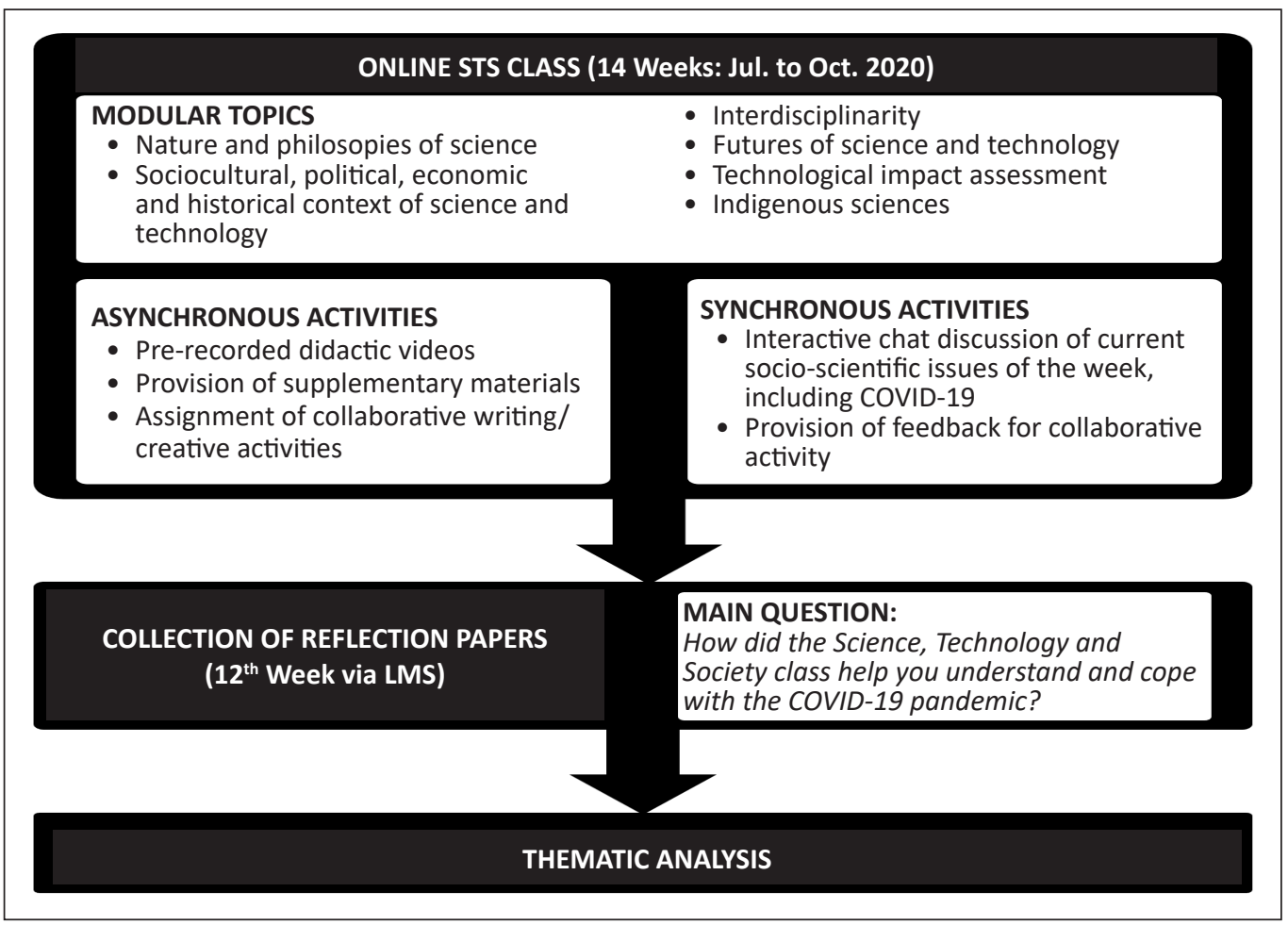

Figure 1. Study procedure 
Table 1

Sample data analysis

\begin{tabular}{|c|c|c|c|}
\hline Sample Excerpt & Sample Codes & $\begin{array}{c}\text { Sub- } \\
\text { themes }\end{array}$ & Theme \\
\hline $\begin{array}{l}\text { Amidst a pandemic, the most valuable lesson I can } \\
\text { derive from learning STS is to remain vigilant in order } \\
\text { to derive the best from the technologies available to } \\
\text { me, and to listen to founded and science-based advice } \\
\text { to ensure my safety and that of others (A03) }\end{array}$ & $\begin{array}{l}\text { vigilance on } \\
\text { emerging } \\
\text { technologies } \\
\text { - science-based } \\
\text { decision making }\end{array}$ & $\begin{array}{c}\text { Deepening } \\
\text { of critical } \\
\text { thinking }\end{array}$ & $\begin{array}{l}\text { Enrichment } \\
\text { of Critical } \\
\text { Thinking } \\
\text { and Social } \\
\text { Engagement }\end{array}$ \\
\hline
\end{tabular}

\section{Theme 1. Appreciation of the Science and Medical Community}

Being exposed to STS education has fostered positive attitudes among students towards scientists, researchers and practitioners, especially in health and digital technology. They have gained deeper awareness about the contributions of science and medicine to address the problems brought about by the pandemic. This theme emerged from two subthemes: appreciation of medical research and appreciation of digital technology.

\section{Subtheme 1.1. Appreciation of Medical}

Research. The students have reported having greater awareness about the painstaking process of medical research, especially during the critical time of the pandemic. Because of this, they expressed their gratefulness towards the hardworking researchers working towards vaccines, treatments and other technologies related to COVID-19, as written by Participants $\mathrm{A} 24$ and $\mathrm{C} 15$ :

"I began to appreciate the efforts of our scientists and researchers for spending time finding and developing the cure for COVID-19...”. (A24)
"With this course, I was able to formulate an in-depth understanding and expanded array of perspectives about the situation and the responses made by the scientific community... stages of vaccine trials follow certain protocols and measures to ensure safety”. (C15)

Their exposure to STS education can make learners have positive attitudes towards the scientific method and its application in developing solutions during the pandemic. As the students learned about the multifaceted role of scientists in responding to the threat of COVID-19, they also realise that the quarantine and transmission mitigation measures mandated in the country were also policies that came from medical research, as mentioned by Participants B05 and B21:
"Especially today, different researchers, scientists, companies, and laboratories have been collaborating and looking for new discoveries about the COVID-19 virus...". (B05) 
"...Science helps the people in the society be contained in the middle of the pandemic, like how they are expected to behave to help the totality". (B21)

\section{Subtheme 1.2. Appreciation of Digital}

Technologies. As the students lived in a restricted world during community quarantine and most of their social and economic interactions are conducted online, STS education gave them a deeper appreciation for the digital technologies that had helped them access their needs despite the physical limitations, as mentioned by Participants A01 and B27:

"COVID-19 has brought about my increased reliance on technology to provide essential services such as the delivery of relevant and accurate news, and allow me to carry out necessary tasks...". (A01)

"During this pandemic, we have used different technologies to stay connected with our family and friends, this includes apps like Zoom, Messenger, and other more. The emergence of modern technologies can help us maintain our physical, emotional, and mental health during this pandemic". (B27)

Students have also expressed their gratitude towards the gadgets and online applications that allowed for e-commerce to flourish during the time of the pandemic, which helped people purchase their goods safely and also have income during these trying times, as Participant B24 mentioned:
"The moment I understand the concepts of STS, as a business major, it has made me realise the importance of it not only in the scientific field but also within the business... for instance, adopting the new practice of using social media as a platform in selling and advertising products, conducting market testing”. (B24)

Students have given more positive valuations on innovations in learning and communication as they recount the hardware and applications they use to pursue their degrees. They became appreciative that if it were not for digital and educational technology, they would not have continued their studies. Participant A34 shared:

"Now that we are living in the new normal that has greatly impacted our interactions with people, technology is needed more than ever. It is now the sole medium of communication, learning, and overall survival... Instead of having face-to-face classes that would have risked our health, we conduct online classes". (A34)

\section{Theme 2. Sensitivity to the Barriers of Scientific Progress during the COVID-19 Pandemic}

STS education has made most students critical about the sociopolitical factors that shape how the pandemic is managed in the Philippines and elsewhere. They wrote about the circumstances that hinder the success 
of science and medicine that led to the unfavourable COVID-19 outcomes in the country and concerns about possible future problems. Under this theme are subthemes: frustrations about government management and scepticism about the competition in the vaccine and treatment development.

\section{Subtheme 2.1. Frustrations about}

Government Management. Many students lament the national government response to the pandemic. As they learn about the political forces of science in STS classes and witness the policies and programs rolled out by the government, they note its lack of attention to and coordination with the scientific community, as described by Participants A15 and C07:

"Philippines has seen little to no improvement in handling the pandemic... because the government is not maximising the scientific resources available for our country. For instance, the country currently has trillions of debt, and yet only two cities have provided mass testing”. (A15)

“...This is very sad because the government is prioritising the restoration of Manila Bay instead of restoring the economy of our country. Hopefully, things would be alright soon and life would get back to normal...". (C07)

Due to their exposure to STS education, the students have been able to see how the different problems such as lack of public trust in science, the poor health care system and corruption in the government are intertwined and had been magnified and aggravated by the pandemic. Their ability to find socio-scientific issues that are entwined with current sociopolitical events have been hastened, as demonstrated by Participant A04:

"Transparency cannot be given, prioritisation to our health sectors cannot be seen. Our government is in great debt because they borrowed money for COVID-19, but improvement in our situation cannot be felt. Education is not accessible by everyone, especially nowadays that we have transitioned to online classes. The list goes on, as they are correlated with one another". (A04)

Subtheme 2.2. Scepticism about the Competition in Vaccine and Treatment Development. Vaccine development programs were still in their early phases when these STS classes were held. Students have learned that competition is a force that drives scientific innovations. Some students are sceptical about how quickly the vaccines are being made and are worried that it could affect the truthfulness of the results and the effectiveness of the final output. Participant A20 wrote:

"Specifically knowing what is really happening in the race for a COVID-19 vaccine. It is alarming and scary at the same time knowing 
people can publicise news, papers, and the like just for the sake of being the 'first' even with substandard knowledge or even skipping clinical trials for a vaccine". (A20)

Students consider competition in science as double-edged. They are concerned that the race to the vaccine and other cures may result in suboptimal products and may harm the population. Participant A12 shared the story of how their father, who tested positive for COVID-19, was given experimental drugs and how they felt uncomfortable about it:

"During the latter part of August, my father tested positive for the coronavirus. He was administered with various trial... One of them even failed in its phase 3 trial, and yet it was still given as a treatment... Even though these trials were done with the best intentions, I can't help but feel that my father has become a guinea pig of scientific research... But because of desperation, we had no choice but to agree and accept the risks". (A12)

Exposure STS education had influenced the students' ability to be critical not only to the adherence to the science in the development of vaccines and cures but also the deployment and distribution of these medical technologies. They worry about the equitability of its distribution, as Participant B22 mentioned "...the pandemic unveiled a line between developing and developed countries. If the vaccine was proved to be successful, who is first in line? The countries with power namely, the superpower." (B22)

\section{Theme 3. Gaining Social Consciousness about the Impacts of the Pandemic}

Because of their exposure to STS education, the students gained deeper awareness regarding the societal impacts of the pandemic, both negative and positive. They were able to see the COVID-19 phenomenon's immediate and long term effects on social life. Under this theme are the subthemes: empathy towards the marginalised and acceptance of the 'new normal.'

Subtheme 3.1. Empathy towards the Marginalized. According to the students, the STS class provided them with an avenue to learn and discuss the socioeconomic impacts of the pandemic and develop concern for the most affected sectors of society. For example, Participant A05 mentioned his worry about those who had lost their income opportunities because of COVID-19:

"Right now, we see people struggling with finances as the majority of the labour force do not have a stable job while others are being laid off. Knowing this, makes you wonder whether they are even capable of bringing meals to the table for their families; or if they 
can afford a roof over their heads".

(A05)

Due to STS education, the students have gained more class consciousness. They have a more critical view of the inequalities in society as manifested in the way the pandemic is managed. They have critically observed how the rich and powerful who violate protocols are not as severely sanctioned compared to poorer constituents in society. Participants B29 and A02 explained:

"Every topic learned in STS can be applied and is related in the pandemic today... where upper class abuse their power by getting VIP treatments which is unfair for the lower class especially those who are in need to be treated". (B29)

"Learning STS ... opened my eyes to more harsh realities such as preferential treatment of others especially in terms of the imposition of penalties regarding quarantine guidelines by the influence of their wealth and stature in society...". (A02)

Aside from the loss of income, unemployment, hunger and interrupted access to education, some students also empathise with people experiencing mental health challenges because of the pandemic, as Participant $\mathrm{C} 15$ verbalised:

"With my observations to this COVID 19 crisis, people tend to become paranoid and worried which is not recommendable respond to this type of situation. News and information have great [ly] affected the people in the way they perceived these facts. Some of them have developed over-thinking mindset that have resulted to mental stress and conditions...". (C15)

\section{Subtheme 3.2. Acceptance of the 'New}

Normal'. Because of their exposure to the topic of the future of science, the students have understood that the abrupt changes in society to address needs during quarantine are needed and inevitable. Participant C03 wrote:

"At this time of the pandemic, everyone is obliged to adjust to the new normal. New rules are being implemented for a more effective response to COVID-19, and these are mostly tech-driven... every movement relies on digital technology and the governments are being urged to expand the effective use of it in order to cope with the problem adequately...". (C03)

Students shared that new ways of living such, as an increased focus on hygiene and digital technologies for education and industry, must be continued even after the pandemic, as their benefits are experienced during this time. Participant C18 mentioned the increasing digital literacy of the population because of the pandemic: 
" $S T S$ has helped me in understanding and adapting to the changes and challenges brought about by the COVID-19 pandemic because it gave light to technology playing a big role in aiding us as we perform everyday tasks with the 'new normal'. Technology is the reason we are able to do many things-and even productively, for that matter...”. (C18)

Because of STS education, students have also gained a more critical foresight of a post-COVID world. As a result, they expect to see pandemic-induced practices such as hygiene measures and remote learning become more mainstream. In addition, Participant A05 wrote:

"In the future, it will not be a surprise if we tend to order more take outs than eating inside a restaurant. Some people may believe that they don't need a gym if they need to work out since they can just do it at home". (A05)

\section{Theme 4. Enrichment of Critical Thinking and Social Engagement}

In many instances in the reflection papers, the students expressed how STS education fostered positive changes in their knowledge and attitudes about their realities. Some claim that the course also helped them adapt better to the pandemic. Under this theme are subthemes: deepening of critical thinking and commitment towards social engagement.

\section{Subtheme 4.1. Deepening of Critical} Thinking. Students reported that STS education has helped enhance their critical thinking, not only about the turnout of events during the pandemic but also about the daily technologies they use and how all they embedded in sociocultural contexts. For example, Participant A16 described how wearing the STS lens would allow them to see the world more critically:

"STS has equipped me with the proper tools to make sensible decisions that contribute to the alleviation of the countless problems the outbreak has generated... STS has surely altered my outlook on life... since most lessons, if not all, were extremely relevant and thought-provoking. It has ignited my curiosity and motivated me to view certain social issues from varying perspectives". (A16)

The students were also able to appreciate the value of understanding socio-scientific issues and using STS lenses not only as academic exercises but also basic tools that they can use in order to improve their living, as Participant A06 shared:

“...it has motivated me to keep innovating not only in academics but even in my personal life... to input the concept of continuous improvement in order to keep growing and discovering more about ourselves and the world around us...". (A06) 
Aside from demonstrating a critical understanding of the interrelations of science, technology and society, the students also gained better research and information literacy. They report becoming more curious and investigative about learning and sceptical about daily data that they encounter. Participants A05 and C06 explained that the scientific attitude could be a lifestyle:

"...the course taught me how to be more vigilant in reading articles online as there are a lot of fake news and trolls. It is best for us to do our own research and fact check the articles that we are reading...". (A05)

"...we should always research first and not act hastily... information travels a lot faster though not all information on the internet is correct, it is up to us to analyse which one is trustworthy ... it made me have a deeper connection with science not just as a subject but also as a lifestyle...". (C06)

\section{Subtheme 4.2. Commitment towards} Social Engagement. Being exposed to the successes and problems of science and society, the students have expressed about using their new competencies to contribute in their ways. For example, Participant A04 mentioned their desire to work to address problems in the country:

"Learning about these makes me want to become the change that the country needs. I had this sense of wanting to work in the future for the Philippines, because if nobody cares, then we will be stuck receiving this improper service forever that the Filipinos do not deserve". (A04)

Because they understood the scientific and social bases of the lockdown and the measures mandated upon people to control the pandemic, the students have been more inclined to engage in these protective behaviours to help control the spread of COVID-19, as Participant B22 wrote:

"All the practices and technology that we have now like sanitizing, wearing face masks and face shields, mass temperature testing... were made to avoid the transfer of the virus. As we saw their purpose, it became integrated into our everyday lives... it can actually better our lives". (B22)

Students have also expressed their commitment to using the learnings they obtained from STS to spread awareness and contribute to their respective communities. As C02 narrated:

"Every time I attend class, I am able to pick up new information about current events and I use this knowledge to educate other people as well. I am able to raise awareness and provide a space of learning for others". (C02) 
Ultimately, STS students have earned a more profound sense of their role and responsibilities in nation-building as privileged citizens to have access to a college education. As today's youth, and the future's leaders, they have committed themselves to instil positive change in the world, as Participant C08 mentioned:

"Vision a progressive nation; no
matter what waves of challenges
may come, we must ride onto it.
Accept the fact that we are the
future drivers of change. That as
we see those issues and conflicts
around us, we must take action".
$(\mathrm{C} 08)$

\section{DISCUSSION}

The present study suggests that due to STS education, the students have developed positive attitudes towards scientific research and technological advances, especially those that addressed the needs of the pandemic. This finding confirms Chowdhury (2016) assertion that STS education promotes a deeper understanding of the role of science in society. Furthermore, the STS approach in teaching has improved scientific attitude in the natural (Akcay \& Akcay, 2015; Devi \& Aznam, 2019) and health sciences (Knopes, 2019).

The present research also found that exposure to STS concepts has made the undergraduate students more sensitive about the various forces that impede science's success, especially during the pandemic. For example, students have been highly critical of the government's COVID-19 response and lack of communication with scientific bodies and highly sceptical about the abrupt movement of COVID-19 research on vaccines and other treatments brought about by competition. This finding confirms Çalik and Karatas (2019) that STS education can improve scepticism towards science and socio-scientific issues. Likewise, previous studies have demonstrated how STS can make students learn about the social, cultural and moral forces that affect scientific progress (Khishfe et al., 2017; Yapıcığlu \& Kaptan, 2017). Through STS and discussion of socio-scientific issues, students have realised that science can be used negatively to the detriment of humans and society (Yapıcıoğlu \& Kaptan, 2017).

Students of the present study have also demonstrated heightened social consciousness and empathy towards the marginalized sectors of society disproportionately affected by the pandemic. They have also expressed their increased acceptance of the new normal. This result corroborates Raveendran (2021) that demonstrated how exposure to socioscientific issues could foster the ability to be more analytical about the social inequalities and cultural contexts that influence scientific advancements. The present study has demonstrated the aspirations of Hodson (2020) in providing STS education that fosters critical awareness among students, making them politically literate.

Finally, the present study suggests that the students exposed to STS education have experienced an enhancement of 
critical thinking and scientific stance. Previous studies have demonstrated how STS approaches have improved learners' higher-order thinking (Boonprasert et al., 2018; Ngaewkoodrua \& Yuenyong, 2017) and scientific attitudes (Akcay \& Akcay, 2015; Alcantara, 2000; Devi \& Aznam, 2019) in different topics. Moreover, students participants in this current study have committed to becoming more socially engaged with the issues emerging from the COVID-19 pandemic. This finding supports Chowdhury et al. (2020), which argues that science education embedded in socio-scientific issues can promote the desired citizenry by orienting them in local and global issues and promoting student participation.

\section{CONCLUSION}

This present study provides qualitative evidence of the relevance of STS education in deepening the critical understanding and sense-making of the COVID-19 pandemic among undergraduate students. Exposure to the course can develop both appreciation and scepticism on the role and impact of the scientific community and other social forces during the pandemic. Moreover, STS equips students with knowledge and attitudes that can empower them to become socially responsible individuals that can contribute to society's adaptation during the pandemic — and beyond.

\section{Implications}

More than a year since the discovery of COVID-19, the virus has continued to impact everyone's lives negatively. Its impact on society and the economy is expected to extend beyond the pandemic. STS approaches can be used not only in STS courses but also in other subjects in the social sciences, hard sciences, engineering, and mathematics to further assist students in navigating society in these difficult times and future problems. Educators must continue integrating current scientific and sociopolitical events in their lessons to make students' learning experiences more relatable, meaningful and applicable.

\section{Limitations}

This study only included three sections of STS classes in one university. Also, the insights of this study are dependent upon the status of COVID-19 and other current events that transpired during the 14 weeks that the classes were conducted. Therefore, it is further recommended that this study be replicated, including more students from different classes and schools, under different professors. Also, follow up studies can be done when the world has entered a postCOVID-19 era.

\section{ACKNOWLEDGMENT}

Author wish to thank the university's Science, Technology and Society course coordinator, Dr Dennis Erasga, and his core team of online course developers Dr Crisanto Regadio, Jr., Mr Patrick Cenon and Mr Jessie Varquez, Jr.

\section{Funding}

None. 


\section{Conflict of Interest}

None.

\section{REFERENCES}

Akcay, B., \& Akcay H. (2015). Effectiveness of science-technology-society (STS) instruction on student understanding of the nature of science and attitudes toward science. International Journal of Education in Mathematics, Science and Technology, 3(1), 37-45. https://www.ijemst. net/index.php/ijemst/article/view/51

Alcantara, A. J. (2000). Assessment of science, technology and society (STS) as a general education course at UP Los Baños. https://agris.fao.org/agris-search/search. do? recordID $=$ PH2001101343

Beltran, M. (2020, May 26). The Philippines' PANDEMIC response: A tragedy of errors. The Diplomat. https://thediplomat.com/2020/05/ the-philippines-pandemic-response-a-tragedyof-errors.

Bettencourt, C., Velho, J. L., \& Almeida, P. A. (2011). Biology teachers' perceptions about ScienceTechnology-Society (STS) education. ProcediaSocial and Behavioral Sciences, 15, 3148-3152. https://doi.org/10.1016/j.sbspro.2011.04.262

Boonprasert, L., Tupsai, J., \& Yuenyong, C. (2018). Grade 8 students' capability of analytical thinking and attitude toward science through teaching and learning about soil and its' pollution based on science technology and society (STS) approach. AIP Conference Proceedings, 1923(1), 030070. https://doi.org/10.1063/1.5019561

Çalik, M., \& Karatas, F. Ö. (2019). Does a "Science, Technology and Social Change" course improve scientific habits of mind and attitudes towards socioscientific issues? Australian Journal of Teacher Education, 44(6), 35-52. http://dx.doi. org/10.14221/ajte.2018v44n6.3

Chowdhury, M. A. (2016). The integration of sciencetechnology-society/science-technology-society- environment and socio-scientific-issues for effective science education and science teaching. Electronic Journal of Science Education, 20(5), 19-38. https://eric.ed.gov/?id=EJ1188220

Chowdhury, T. B. M., Holbrook, J., \& Rannikmäe, M. (2020). Socioscientific issues within science education and their role in promoting the desired Citizenry. Science Education International, 31(2), 203-208. https://doi.org/10.33828/sei. v31.i2.10

Cigdemoglu, C. (2020). Flipping the use of sciencetechnology and society issues as triggering students' motivation and chemical literacy. Science Education International, 31(1), 74-83. https://doi.org/10.33828/sei.v31.i1.8

Cleofas, J. V. (2021). Life interruptions, learnings and hopes among Filipino college students during COVID-19 pandemic. Journal of Loss and Trauma, 26(6), 552-560. https://doi.org/10.108 $0 / 15325024.2020 .1846443$

Commission on Higher Education (2013). General education curriculum: Holistic understandings, intellectual and civic competencies. https:// ched.gov.ph/wp-content/uploads/2017/10/CMONo.20-s2013.pdf

Devi, M. G., \& Aznam, N. (2019). The effect of science-technology-society (STS) model on scientific literacy and scientific attitude of students on the subject of buffer. Journal of Physics: Conference Series, 1156(1), 012027.

Fitsch, H., Jordan-Young, R., Trujillo, A. K., Kraus, C., Roy, D., \& Schmitz, S. (2020). Coalitionmaking and the practice of feminist STS in the time of COVID-19. Catalyst: Feminism, Theory, Technoscience, 6(2), 1-33. https://doi. org/10.28968/cftt.v6i2.34640

Hodson, D. (2020). Going beyond STS education: Building a curriculum for sociopolitical activism. Canadian Journal of Science, Mathematics and Technology Education, 20(4), 592-622. https:// doi.org/10.1007/s42330-020-00114-6 
Khishfe, R., Alshaya, F. S., BouJaoude, S., Mansour, N., \& Alrudiyan, K. I. (2017). Students' understandings of nature of science and their arguments in the context of four socio-scientific issues. International Journal of Science Education, 39(3), 299-334. https://doi.org/10.1 080/09500693.2017.1280741

Knopes, J. (2019). Science, technology, and human health: The value of STS in medical and health humanities pedagogy. Journal of Medical Humanities, 40(4), 461-471. https://doi. org/10.1007/s10912-019-09551-3

Lasco, G. (2020). Medical populism and the COVID-19 pandemic. Global Public Health, 15(10), 1417-1429. https://doi.org/10.1080/174 41692.2020.1807581

Mulyanti, S., Halim, A., Ilyas, S., \& Syukri, M. (2020, October 20-22). The impact of the science technology society (STS) approach on critical thinking ability and student learning outcomes. Journal of Physics: Conference Series, 1882, 012026.

Ngaewkoodrua, N., \& Yuenyong, C. (2017, June 6-8). Teachers' learning on the workshop of STS approach as a way of enhancing inventive thinking skills. AIP Conference Proceedings, 1923(1), 030030). https://doi. org/10.1063/1.5019521

Olukotun, O., Mkandawire-Vahlmu, L., Kreuziger, S. B., Dressel, A., Wesp, L., Sima, C., Scheer, V., Weitzel, J., Washington, R., Hess, A., Kako, P., \& Stevens, P. (2018). Preparing culturally safe student nurses: An analysis of undergraduate cultural diversity course reflections. Journal of Professional Nursing, 34(4), 245-252. https:// doi.org/10.1016/j.profnurs.2017.11.011

Raveendran, A. (2021). Invoking the political in socioscientific issues: A study of Indian students' discussions on commercial surrogacy. Science Education, 105(1), 62-98. https://doi. org/10.1002/sce.21601

Roswita, F., Sulastri, S., \& Khaldun, I. (2021). Application of the Science Technology Society (STS) model to craft and entrepreneurship materials to develop soft skills of students. Jurnal Penelitian Pendidikan IPA, 7(1), 67-73. https://doi.org/10.29303/jppipa.v7i1.525

Smith, J. A. (2017). Textual analysis. The International Encyclopedia of Communication Research Methods, 1-7. https://doi. org/10.1002/9781118901731.iecrm0248

Terry, G., Hayfield, N., Clarke, V. \& Braun, V. (2017). Thematic analysis. In Willig, C. \& Stainton-Rogers (Eds.), The Sage handbook of qualitative research in psychology (2nd ed., pp. 17-37). Sage.

Talidong, K. J. B., \& Toquero, C. M. D. (2020). Philippine teachers' practices to deal with anxiety amid COVID-19. Journal of Loss and Trauma, 25(6-7), 573-579. https://doi.org/10.1080/1532 5024.2020 .1759225

Toquero, C. M. (2020). Challenges and opportunities for higher education amid the COVID-19 pandemic: The Philippine context. Pedagogical Research, 5(4), em0063. https://doi. org/10.29333/pr/7947

World Health Organization. (2021). Weekly epidemiological update - 16 February 2021. https://www.who.int/publications/m/ item/weekly-epidemiological-update---16february-2021

Yapıcıoğlu, A. E., \& Kaptan, F. (2017). A mixed method research study on the effectiveness of socioscientific issue-based instruction. Education and Science, 42(192), 113-137. https://doi. org/10.15390/EB.2017.6600 